\title{
THE IMMIGRANT
}

\section{BILLA SAMGWA}

\section{ARTIST STATEMENT}

This song is titled "Immigrant," and it's in two parts: the first part of the song reflects on the general reasons why some of us find ourselves wanting to leave our countries of origin, the struggles of actually managing to get to our destination countries, and the difficulties we face on a daily basis as immigrants. The second part of the song is more personal-the issues I have faced in over three years of living in Germany, and how people react to me because of my skin colour, both at work and at social gatherings.

\section{KEYWORDS}

immigration, racism, diaspora, marginalized

\section{$\underline{A U D I O} \mathrm{LINK}$}

\section{LYR I C S}

Young boy all the way from Africa.

Ride through the sea with the boat yo.

Walking barefeet through the desert.

Am a hussler you can take that.

Where I come from people die yo.

Government trash they don't care yo.

Family starve they gon die yo.

Shit really hurts when you think about it.

Playing hide and seek with dem live bullets.

Tryna protests you gon get killed.

Voice of the poor never get heard.

Rich people chill la vida loca.

If I tell you what I been through yo.

You will never look at me the same yo. 2x

Saw friends come back from Europe yo.

Flashing big cars with dem big chains.

Build houses put their fams in.

Then I tell myself ama do same.

By any means ama get there.

I don't care how hard that it gets yo 
Ama push through till I get there. Anyways somehow I get rich. Go back home live a chilled life. Make myself rich and my family I don't want no damn problems Am not a threat to your lively hood.

Whiteman Whiteman whitemannn know that your government fucking us.

Every resources that we get yeah know that they bring it all straight to you. $2 \mathrm{x}$

Shut your dumb ass you ignorant. Immigration is a business, That your government is feeding right off. Educate yourself or you stop talking. Everybody screaming they gon take our jobs. Tell me what jobs do you talk about. Minimum wage that's the job we do. 8 euros job never seen you do.

Zeit firma, leih arbeit, cleaning bathrooms in the clubs yo. Burger king, McDonald's. Tell me when last did you do that. $2 x$

Take a sit, sit back. Listen.

Ama tell you. What I. Go through. Black boy. White world. Racism, hatred.

Stay home, 24/7

On the streets, gat attacked. By Nazis.

Left ma home since 3 years.

Never went back a visit no.

Men I really miss my whole fam.

Lost all friends since I gat here.

Cuz they all think that I made it ha. They gat no idea how hard it is. Wake up in this place every day and night. No.

Once you are black you illiterate. 
Once you are black you deserve less.

Once you are black you dangerous.

Once you are black you a drug dealer.

Things like this they hurt deep.

Stereotypes everywhere like fresh air.

Nobody cares if you die no.

People look at you like animal

If you die for them then it's one less.

I hold ma heart, then I look up.

I tell myself. Boy you different.

Loneliness is my best friend.

Cuz nobody understands me.

They judge me from the way I look.

But am different in my heart.

I just want you. To see me. As a human

being. That I really am.

Billa is a hip hop recording artist. He is originally from Cameroon and has been living as an immigrant in Germany for over three years. 